\title{
Optimal Capital Accumulation and Corporate Investment Behavior
}

\section{Citation}

Jorgenson, Dale W., and Calvin D. Siebert. 1968. Optimal capital accumulation and corporate investment behavior. Journal of Political Economy 76(6): 1123-1151.

\section{Published Version}

http://dx.doi.org/10.1086/259478

\section{Permanent link}

http://nrs.harvard.edu/urn-3:HUL.InstRepos:3403057

\section{Terms of Use}

This article was downloaded from Harvard University's DASH repository, and is made available under the terms and conditions applicable to Other Posted Material, as set forth at http:// nrs.harvard.edu/urn-3:HUL.InstRepos:dash.current.terms-of-use\#LAA

\section{Share Your Story}

The Harvard community has made this article openly available.

Please share how this access benefits you. Submit a story.

\section{Accessibility}




\section{CHICAgo JOURnals}

Optimal Capital Accumulation and Corporate Investment Behavior

Author(s): Dale W. Jorgenson and Calvin D. Siebert

Source: The Journal of Political Economy, Vol. 76, No. 6 (Nov. - Dec., 1968), pp. 1123-1151

Published by: The University of Chicago Press

Stable URL: http://www.jstor.org/stable/1830154

Accessed: 07 $/ 11 / 2009$ 12:44

Your use of the JSTOR archive indicates your acceptance of JSTOR's Terms and Conditions of Use, available at http://www.jstor.org/page/info/about/policies/terms.jsp. JSTOR's Terms and Conditions of Use provides, in part, that unless you have obtained prior permission, you may not download an entire issue of a journal or multiple copies of articles, and you may use content in the JSTOR archive only for your personal, non-commercial use.

Please contact the publisher regarding any further use of this work. Publisher contact information may be obtained at http://www.jstor.org/action/showPublisher?publisherCode=ucpress.

Each copy of any part of a JSTOR transmission must contain the same copyright notice that appears on the screen or printed page of such transmission.

JSTOR is a not-for-profit service that helps scholars, researchers, and students discover, use, and build upon a wide range of content in a trusted digital archive. We use information technology and tools to increase productivity and facilitate new forms of scholarship. For more information about JSTOR, please contact support@jstor.org.

The University of Chicago Press is collaborating with JSTOR to digitize, preserve and extend access to The Journal of Political Economy. 


\section{Optimal Capital Accumulation and Corporate Investment Behavior}

\section{Dale W. Jorgenson}

University of California, Berkeley

\section{Calvin D. Siebert}

University of Iowa

\section{Introduction}

In a previous paper we tested a theory of investment behavior based on the neoclassical theory of the firm at the level of the individual corporation (Jorgenson and Siebert, 1968). More specifically, we have compared the neoclassical theory with alternative explanations of corporate investment behavior based on considerations of liquidity, expected profits, and capacity utilization. For any of the conventional measures of goodness of fit-minimum residual variance, conformity of turning points, number of coefficients exceeding twice their standard errors-the performance of the neoclassical theory is superior to that of the alternative theories. ${ }^{1}$

In this paper we study the neoclassical theory of corporate investment behavior in more detail. We begin by outlining a theory of optimal capital accumulation based on maximization of the market value of the firm. From a purely formal point of view, the theory is simply the intertemporal analogue of the usual atemporal theory based on profit maximization. Under our characterization of technology, a more direct connection with profit maximization may be developed. Maximization of the value of the firm implies maximization of profit at each point of time, where profit is defined as the difference between net revenue on current account and the implicit rental value of capital services supplied by the firm to itself. The implicit rental is calculated through a "shadow" or accounting price for capital services that depends on the cost of capital, the price of investment goods, the rate of change of this price, and the tax structure for business income. ${ }^{2}$ Of course, profit in this sense differs from the usual accounting definition for tax purposes.

\footnotetext{
${ }^{1}$ Detailed comparisons of the performance of the alternative theories of corporate investment are given in Jorgenson and Siebert (1968, Tables 2, 4, and 5).

${ }^{2}$ Equivalence between maximization of the market value of the firm and maximization of profit at each point of time is discussed by Malinvaud (1953) and, more recently, by Arrow (1964). The essential idea is implicit in Haavelmo's theory of investment (1960).
} 
The neoclassical theory of optimal capital accumulation implies a theory of the cost of capital. The market value of the firm is equal to the discounted value of cash flow net of direct taxes. The appropriate after-tax rate of discount is the cost of capital employed in the accounting price for capital services used in the choice of an optimal level of capital services at each point of time. The cost of capital can be measured from net cash flow, the market value of the firm, and the change in this market value. This theory of the cost of capital has been developed by Modigliani and Miller (1958, 1966).

While the neoclassical theory assigns an important role to the cost of capital, it also attributes considerable importance to the rate of change of the price of investment goods. Changes in this price result in capital gains and losses that must be included in the calculation of economic profit or loss associated with alternative production plans. Holding the other determinants of the price of capital services constant, a high rate of change of prices of investment goods should provide an incentive to use more capital, while a low rate of change should serve as a disincentive. One of the purposes of this paper is to evaluate the effects of inflation on the level of investment. The rate of inflation will be studied along with other determinants of the implicit rental for capital services, including the cost of capital, the level of prices of investment goods, and the tax structure.

We take the level of capital determined by maximization of the market value of the firm as the desired level. By permitting discrepancies between desired and actual levels of capital, the model can incorporate the effects of gestation lags in investment and lags between actual and expected values of the determinants of investment. With perfect foresight, the actual and expected values of these determinants would be identical and the actual level of capital would always equal the desired level. Thus, we relax the assumption of perfect foresight that underlies conventional treatments of the neoclassical theory of optimal capital accumulation. Our model of investment takes account of uncertainty through the use of stock-market information to infer the cost of capital and through permitting discrepancies between actual and desired levels of capital.

\section{Theoretical Framework}

In the neoclassical theory of corporate investment behavior, the firm selects a production plan so as to maximize its market value. For the description of technology we adopt, maximization of market value is implied by maximization of profit at every point of time, present and future, where profit is defined as net revenue on current account less the implicit rental value of capital services. We call the resulting level of demand for capital services the desired level of capital. If desired and actual levels of capital are 
always equal, investment is simply the change in desired capital plus replacement investment. We assume that desired and actual levels may be different, but that in each period new investment goods are ordered up to a level that will equate desired and actual capital when all outstanding orders have been delivered. Actual delivery is assumed to be distributed over time, so that investment net of replacement is a distributed lag function of past changes in the level of desired capital services. By permitting desired and actual levels of capital to differ, we relax the assumption of perfect foresight that underlies the conventional treatment of neoclassical theory. Such differences are not consistent with the assumption of perfect foresight, even if allowance is made for the fact that the investment process requires time. An economic agent with perfect foresight can plan investment projects so that the projects are completed at exactly the moment the need for them arises.

To complete the theory of investment behavior, it is necessary to specify the determinants of replacement investment. We assume that replacement is proportional to capital stock at the beginning of the period. In repeated tests, both at the aggregate level and for individual firms, this theory has proved satisfactory as a representation of replacement investment. ${ }^{3}$

More formally, the market value of the firm is defined as the discounted value of cash flow less direct taxes; cash flow is the value of output less the value of expenditures on current account and outlays on capital account:

$$
R=p Q-s L-q I,
$$

where $R$ is the cash flow, $p$ the price of output and $Q$ the quantity, $s$ the price of current input and $L$ the quantity, and $q$ the price of investment goods and $I$ the quantity. In addition to its outlays for current inputs and investment goods, the firm must also pay direct taxes, say $D$; these taxes must be deducted from cash flow in calculating the value of the firm. The market value is the discounted value of cash flow net of direct taxes:

$$
W(t)=\int_{t}^{\infty} e^{-\int_{t}^{\tau} r(\theta) d \theta}[R(\tau)-D(\tau)] d \tau,
$$

where $W$ is market value and $r$ the cost of capital. At each point of time, the objective of the firm is to maximize its market value.

The amount of direct taxes at any point of time depends on the tax structure. A first approximation to the corporate tax structure for the United States may be obtained by assuming that the rate of tax is constant at any point of time and that business income for tax purposes is defined as revenue on current account less outlays on current account and certain

${ }^{3}$ See Meyer and Kuh (1957, pp. 91-94) and Jorgenson and Stephenson (1967b, pp. 192-212). 
deductions on capital account; these deductions are proportional to replacement, to the cost of capital, and to capital gains or losses on assets. Direct taxes may then be represented as:

$$
D=u\left[p Q-s L-q\left(w \delta+v r-x \frac{\dot{q}}{q}\right) K\right],
$$

where $u$ is the tax rate and $w$ the proportion of replacement, $v$ the proportion of cost of capital, and $x$ the proportion of capital losses deductible for tax purposes. The rate of replacement, $\delta$, is assumed to be constant. For our sample of corporations, the proportions of cost of capital and capital losses deductible for tax purposes are negligible, so that the expression for direct taxes may be simplified:

$$
D=u(p Q-s L-w \delta q K) .
$$

Needless to say, numerous features of the U.S. tax structure are not represented explicitly in this formulation; however, even this simplified form allows for variations in the tax rate and in provisions for depreciation allowances over time.

The market value of the firm is maximized, subject to a production function:

$$
Q=F(K, L) .
$$

Output depends on input of capital services and current input. The rate of investment must be related to the quantity of capital services available; we assume that replacement is proportional to capital stock, so that net investment equals the difference between investment and replacement:

$$
\dot{K}=I-\delta K \text {. }
$$

As before, the rate of replacement, $\delta$, is assumed to be constant. Further, we assume that the flow of capital services at every point of time is proportional to capital stock. This description of technology makes possible the correspondence between maximization of value of the firm and maximization of profit suggested above. Before developing this correspondence, we consider the definition of the cost of capital.

The cost of capital in the expression for the market value of the firm is an after-tax rate of discount. Differentiating the market value of the firm with respect to time, we obtain:

$$
r=\frac{R-D}{W}+\frac{\dot{W}}{W}
$$

The cost of capital is cash flow net of direct taxes divided by the market value of the firm plus the rate of growth of the market value. An essentially equivalent definition has been used by Modigliani and Miller $(1958,1966){ }^{4}$

${ }^{4}$ Measurement of the cost of capital from accounting data is discussed in the Statistical Appendix to a more extensive multilithed version of this paper available from the authors. 
For maximization of the market value of the firm subject to the production function and the constraint relating investment to change in capital, the necessary conditions are identical to conditions for maximization of profit before taxes at each point of time, ${ }^{5}$ where profit is defined as:

$$
P=p Q-s L-c K \text {. }
$$

The unit rental of capital, $c$, is the "shadow" or accounting price of capital services before taxes:

$$
c=\frac{q}{1-u}\left[r+(1-u w) \delta-\frac{\dot{q}}{q}\right] .
$$

Comparing the definition of profit (7) with the definition of business income for tax purposes in (3), we see that profit excludes the cost of capital and includes capital gains whether realized or not. Depreciation for tax purposes is not necessarily equal to economic depreciation. We conclude that the concept of profit appropriate for maximization of the market value of the firm is not identical to business income as defined for tax purposes. It should come as no surprise that businessmen express little interest in the maximization of accounting "profit." The appropriate criterion is maximization of profit defined in a special sense as revenue minus cost on current account less the implicit rental value of capital services.

To complete the empirical formulation of the theory of corporate investment, we assume that the production function (4) may be taken to be Cobb-Douglas in form. Under this assumption, the desired level of capital, say $\mathrm{K}^{+}$, is proportional to the value of output divided by the price of capital services,

$$
K^{+}=\alpha \frac{p Q}{c},
$$

where $\alpha$ is the elasticity of output with respect to capital services. ${ }^{6}$ Second, we assume that investment projects to expand capacity require time for completion so that net investment in every period is a weighted average of past starts. Finally, we assume that at each point of time new investment projects are initiated so as to equate desired and actual capital services when all projects underway are completed. The level of new starts is equal to the change in desired capital from period to period. Under these assumptions, net investment is a distributed lag function of past changes in the level of desired capital.

${ }^{5}$ These necessary conditions are derived by Jorgenson (1965, pp. 43-47). This analysis is easily extended to optimal capital accumulation with any number of assets, including inventories and working capital.

${ }^{6}$ For a detailed derivation, see Jorgenson (1965, p. 53). An interesting set of results supporting the Cobb-Douglas function at the level of the individual firm has recently been presented by Eisner (1967a). 
To make notation for a distributed lag function concise, we introduce the lag operator, $L$, defined as: $L x_{t}=x_{t-1}$. With this notation, the final form of the distributed lag function used in our empirical work is:

$$
I_{t}=\gamma(L)\left(K_{t}^{+}-K_{t-1}^{+}\right)+[1-\omega(L)]\left(I_{t}-\delta K_{t}\right)+\delta K_{t-1}+\epsilon_{t},
$$

where the time structure of investment behavior is characterized by the polynomials in the lag operator, $\gamma(L)$ and $\omega(L) .{ }^{7}$ The sequence of random errors, $\epsilon_{t}$, is assumed to have expected value zero, constant variance, and to be serially independent. As an example, if the distributed lag function involves current and lagged changes in desired capital and lagged net investment, the final form of the distributed lag function may be written:

$$
\begin{aligned}
I_{t}=\alpha \gamma_{0}\left(\frac{p_{t} Q_{t}}{c_{t}}-\frac{p_{t-1} Q_{t-1}}{c_{t-1}}\right)+\alpha \gamma_{1} & {\left[\frac{p_{t-1} Q_{t-1}}{c_{t-1}}-\frac{p_{t-2} Q_{t-2}}{c_{t-2}}\right] } \\
& -\omega_{1}\left(I_{t-1}-\delta K_{t-1}\right)+\delta K_{t-1}+\epsilon_{t} .
\end{aligned}
$$

\section{Empirical Results}

In developing and testing a theory of corporate investment behavior, we have attempted to avoid biases that could arise from inappropriate assumptions about the homogeneity of investment behavior across firms. Data on individual firms have been analyzed using both time series and cross-section models. The study of Meyer and Kuh (1957) was based primarily on cross sections. Subsequently, Kuh (1963) has shown that cross sections for successive years do not provide a stable explanation of investment behavior. The intercepts for cross sections exhibit a strong pattern of cyclical variation, suggesting that the dynamic specification of the models used for individual cross sections is incorrect. In order to specify the lag structure correctly at the level of the individual firm, we have concentrated on time series data for a small but representative sample of firms selected from the Fortune Directory (1962) of the five hundred largest U.S. industrial corporations for 1962. For each individual firm we determine an appropriate specification of the lag between changes in demand for capital and investment expenditures. We do not assume that the parameters for all firms are the same for cross sections at a given point of time. Further, we do not assume that the time structure of investment behavior is the same for all firms.

To sample a broad range of industrial activity, we selected a total of fifteen firms representing fourteen of the two-digit manufacturing industries. Since 1934, all firms whose stock is traded publicly have had to file annual reports, consisting of complete income statements and balance

${ }^{7}$ For further discussion of this distributed lag function, see Jorgenson (1965, pp. 47-48, 53-55). Statistical methods appropriate for distributed lag functions of this type are given by Jorgenson (1966). 
sheets, with the Securities and Exchange Commission. We excluded firms that lost their identity through mergers during the period and firms that shifted accounting years or changed the degree of consolidation in their financial reports. Limitations of data made it necessary to concentrate on larger firms. We began by selecting the largest firm in each two-digit industry of manufacturing; in some cases, the appropriate data were unavailable for the largest firm, so we selected the next largest firm, and so on. The firms included in our sample are listed in Table 1. Although all of the firms are large, they vary considerably in both size and rate of growth. The average amounts of investment and capital stock for each firm are given in Table 1.

Our dependent variable, gross investment in constant dollars of 1954, is the current value of investment in plant and equipment deflated by the investment goods price index for manufacturing. Capital stock was calculated by selecting an initial and terminal value of depreciable assets net of depreciation, deflating these bench-mark levels by fixed capital stock deflators for the firm's industry group, and interpolating the bench marks by using gross investment in constant prices. The value of output was measured by sales plus the change in inventory stock.

In the neoclassical theory of corporate investment behavior, desired capital is equal to the value of output deflated by the accounting price

TABLE 1

\begin{tabular}{|c|c|c|c|}
\hline Firm & $\begin{array}{c}\text { Average } \\
\text { Amount of } \\
\text { Investment* }\end{array}$ & $\begin{array}{l}\text { Capital } \\
\text { Stock } \dagger\end{array}$ & Two-Digit Industry \\
\hline General Motors & .7670 & 3.1225 & $\begin{array}{l}\text { Motor vehicles and equip- } \\
\text { ment }\end{array}$ \\
\hline $\begin{array}{l}\text { Goodyear Tire and Rubber } \\
\text { American Can } \\
\text { Pittsburgh Plate Glass } \\
\text { United States Steel } \\
\text { General Electric }\end{array}$ & $\begin{array}{l}.0554 \\
.0414 \\
.0345 \\
.2980 \\
.1190\end{array}$ & $\begin{array}{r}.3616 \\
.5374 \\
.3128 \\
2.9437 \\
.7247\end{array}$ & $\begin{array}{l}\text { Rubber products } \\
\text { Other durables } \\
\text { Stone, clay, and glass } \\
\text { Primary iron and steel } \\
\text { Electrical machinery and } \\
\text { equipment }\end{array}$ \\
\hline $\begin{array}{l}\text { Reynolds Tobacco } \\
\text { Du Pont }\end{array}$ & $\begin{array}{l}.0127 \\
.1540\end{array}$ & $\begin{array}{l}.1267 \\
.9404\end{array}$ & $\begin{array}{l}\text { Other non-durables } \\
\text { Chemicals and allied } \\
\text { products }\end{array}$ \\
\hline $\begin{array}{l}\text { Anaconda } \\
\text { Standard Oil, N.J. } \\
\text { International Paper } \\
\text { Westinghouse Air Brake }\end{array}$ & $\begin{array}{l}.0511 \\
.6274 \\
.0563 \\
.0038\end{array}$ & $\begin{array}{r}.7077 \\
6.3560 \\
.4780 \\
.0393\end{array}$ & $\begin{array}{l}\text { Primary non-ferrous metal } \\
\text { Petroleum and coal products } \\
\text { Paper and allied products } \\
\text { Transportation equipment, } \\
\text { excluding motor vehicles }\end{array}$ \\
\hline $\begin{array}{l}\text { International Business } \\
\text { Machines }\end{array}$ & .1839 & .9492 & Machinery, except electrical \\
\hline $\begin{array}{l}\text { Swift } \\
\text { Westinghouse Electric }\end{array}$ & $\begin{array}{l}.0266 \\
.0497\end{array}$ & $\begin{array}{l}.2467 \\
.3841\end{array}$ & $\begin{array}{l}\text { Food and beverage } \\
\text { Electric machinery and } \\
\text { equipment }\end{array}$ \\
\hline
\end{tabular}

* Mean annual gross investment for the postwar period, 1946-1963, in billions of 1954 dollars.

$\dagger$ End-of-year net fixed assets for 1961 in billions of 1954 dollars.

SOURCE.-Jorgenson and Siebert (1968, Table 1). 
of capital services. The price of capital services (8) depends on the cost of capital, the price of investment goods, the rate of change of the price of investment goods, and the tax structure. To measure the rate of return, we define gross business income as the sum of profits before taxes, depreciation, and interest. Gross business income is equal to the value of capital services for all classes of assets. From balance-sheet data we were able to obtain the value of depreciable and depletable assets and the value of inventories and cash plus accounts receivable. We derived an expression for the price of capital services for each of these four classes of assets, using the expression (8) given above with appropriate specializations. The price of capital services for each asset class depends on the cost of capital; given the fact that gross business income is the sum of the values of all capital services, we determine the cost of capital.

To assess the effects of variations in the rate of change of the price of investment goods on the level of investment, we consider two alternative versions of the neoclassical theory. First, we assume that capital gains are taken into account in investment decisions so that the price of capital services is precisely as given above in (8). Second, we assume that capital gains are regarded as transitory in both the price of capital services and the cost of capital. In this formulation, the price of capital services becomes:

$$
c=\frac{q}{1-u}[r+(1-u w) \delta] .
$$

The corresponding measure of the cost of capital excludes the rate of capital gains and losses from the rate of return. We refer to the neoclassical theory including capital gains as Neoclassical I and the theory excluding capital gains as Neoclassical II. Except for the differences in the price of capital services and the cost of capital, the theories are identical.

The best fitting distributed lag function for each of the two versions of the neoclassical theory of corporate investment behavior is presented for the fifteen firms of our sample in Table 2. Distributed lag functions were fitted to data for the postwar period, 1949-63, and for the postwar and prewar period, 1937-41 and 1949-63, combined. For evaluation of the effects of inflation on investment behavior, the postwar data are the most relevant. Data for the prewar period were included in order to examine the effects of adding observations from a period with quite different economic conditions. Since some of the distributed lag functions employ as many as three lagged changes in desired capital, and since data are available only since 1934 , the years $1934-36$ and 1946-48 could not be used for unlagged variables. Data for United States Steel are not available for 1934, and data for Pittsburgh Plate Glass for 1963 are not comparable with those for previous years. The column labeled $X_{1}$ contains the intercept in the regression; columns $X_{2}, X_{3}$, and $X_{4}$ contain estimates of the parameters- $\alpha \gamma_{0}, \alpha \gamma_{1}, \alpha \gamma_{2}$-and columns $X_{5}$ and $X_{6}$ give estimates of the 
parameters $-\omega_{1}, \omega_{2}$; the final column, $X_{7}$, gives an estimate of the rate of replacement, $\delta$.

As an example, the final form of the distributed lag function for General Motors for the Neoclassical I model of corporate investment behavior for the period 1949-63 may be written:

$$
\begin{aligned}
I_{t}=\beta+\alpha \gamma_{0}\left(\frac{p_{t} Q_{t}}{c_{t}}-\frac{p_{t-1} Q_{t-1}}{c_{t-1}}\right)+\alpha \gamma_{1} & \left(\frac{p_{t-1} Q_{t-1}}{c_{t-1}}-\frac{p_{t-2} Q_{t-2}}{c_{t-2}}\right) \\
& -\omega_{1}\left(I_{t-1}-\delta K_{t-1}\right)+\delta K_{t-1}+\epsilon_{t} .
\end{aligned}
$$

Substituting the numerical values from Table 2 for the unknown parameters, we obtain:

$$
\begin{aligned}
I_{t}=.2449+ & .0160\left(\frac{p_{t} Q_{t}}{c_{t}}-\frac{p_{t-1} Q_{t-1}}{c_{t-1}}\right)+\underset{(.0066)}{.0150}\left(\frac{p_{t-1} Q_{t-1}}{c_{t-1}}-\frac{p_{t-2} Q_{t-2}}{c_{t-2}}\right) \\
& (.0063) \\
- & .3444\left(I_{t-1}-\delta K_{t-1}\right)+.1794 K_{t-1} . \\
& (.2061) \quad(.0540)
\end{aligned}
$$

Similar results are given for the Neoclassical II model of corporate investment behavior. Results are given for the postwar period, 1949-63, and for the combined prewar and postwar period, 1937-41 and 1949-63, for all fifteen firms included in our sample. For Du Pont, the Neoclassical II model does not provide a sufficiently good explanation of investment behavior that any of the lagged changes in desired capital lower the standard error of the regression; therefore, no empirical results are given for this model for Du Pont. Goodness-of-fit statistics for the neoclassical models - the coefficient of multiple determination, $R^{2}$; the standard error of the regression, $s$; and the Durbin-Watson ratio, $d$-are also given in Table 2.

None of the estimates given in Table 2 constrains the coefficients of the distributed lag function to be non-negative. Where the unconstrained estimates failed to satisfy the non-negativity constraint, this constraint was employed to obtain revised estimates. ${ }^{8}$ The constrained estimates for the postwar period are given in Table 3. This table has the same format as Table 2, and the results may be interpreted by analogy with those for Table 2. The sum of the coefficients of the polynomial $\gamma(L)$ must equal the sum for $\omega(L)$. Using this fact, we separate the estimates of the parameters- $\gamma_{0}, \gamma_{1}, \gamma_{2}-$ from our estimates of the parameters- $\alpha \gamma_{0}, \alpha \gamma_{1}, \alpha \gamma_{2} .{ }^{9}$

${ }^{8}$ Necessary and sufficient conditions for non-negativity are given by Jorgenson (1966, pp. 146-47). The procedure employed by Jorgenson and Stephenson (1967b) was used, except for Neoclassical I for American Can and Reynolds Tobacco and for Neoclassical II for Reynolds Tobacco. For American Can, the constraint $\gamma_{2} \geq \omega_{1} \mu_{1}+\omega_{2} \mu_{0}$ was violated; accordingly, the regression was rerun with $\gamma_{2}=0$. For Reynolds Tobacco, the parameter $\omega_{2}$ was allowed to differ from zero in the Neoclassical I model, while the parameter $\delta$ was set equal to zero in the Neoclassical II model.

${ }^{9}$ The method of estimation is discussed by Jorgenson (1966, p. 148). 


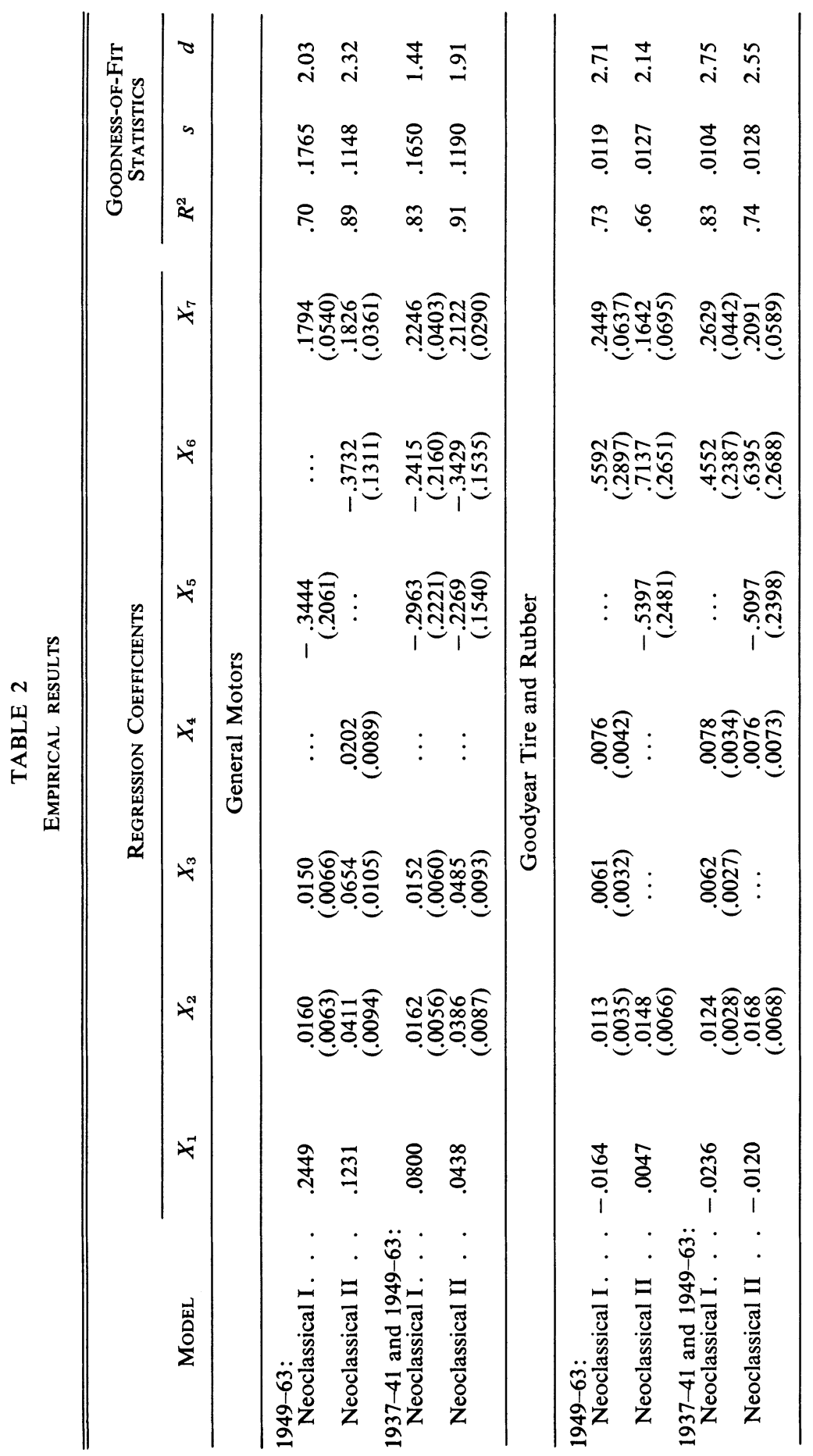




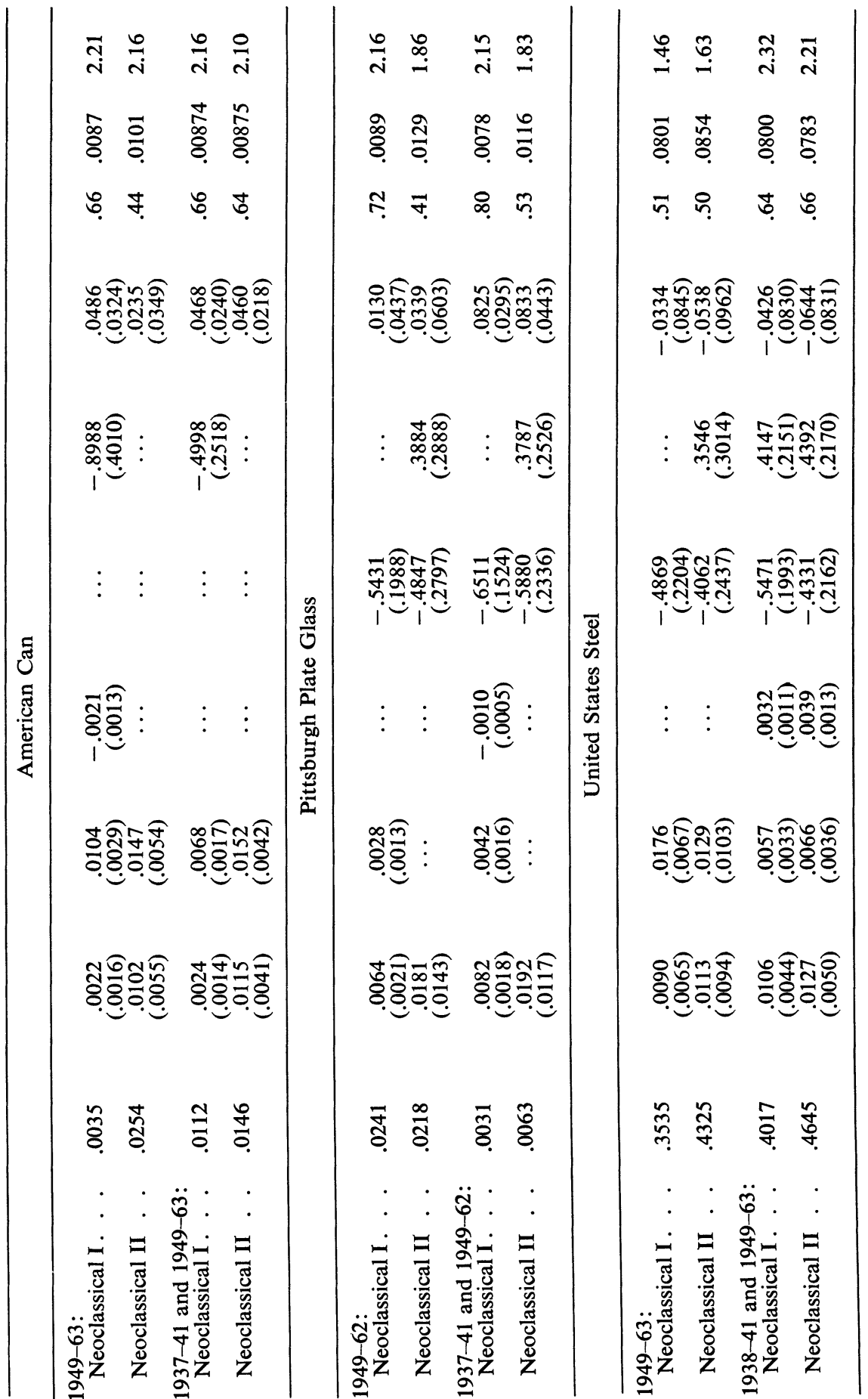




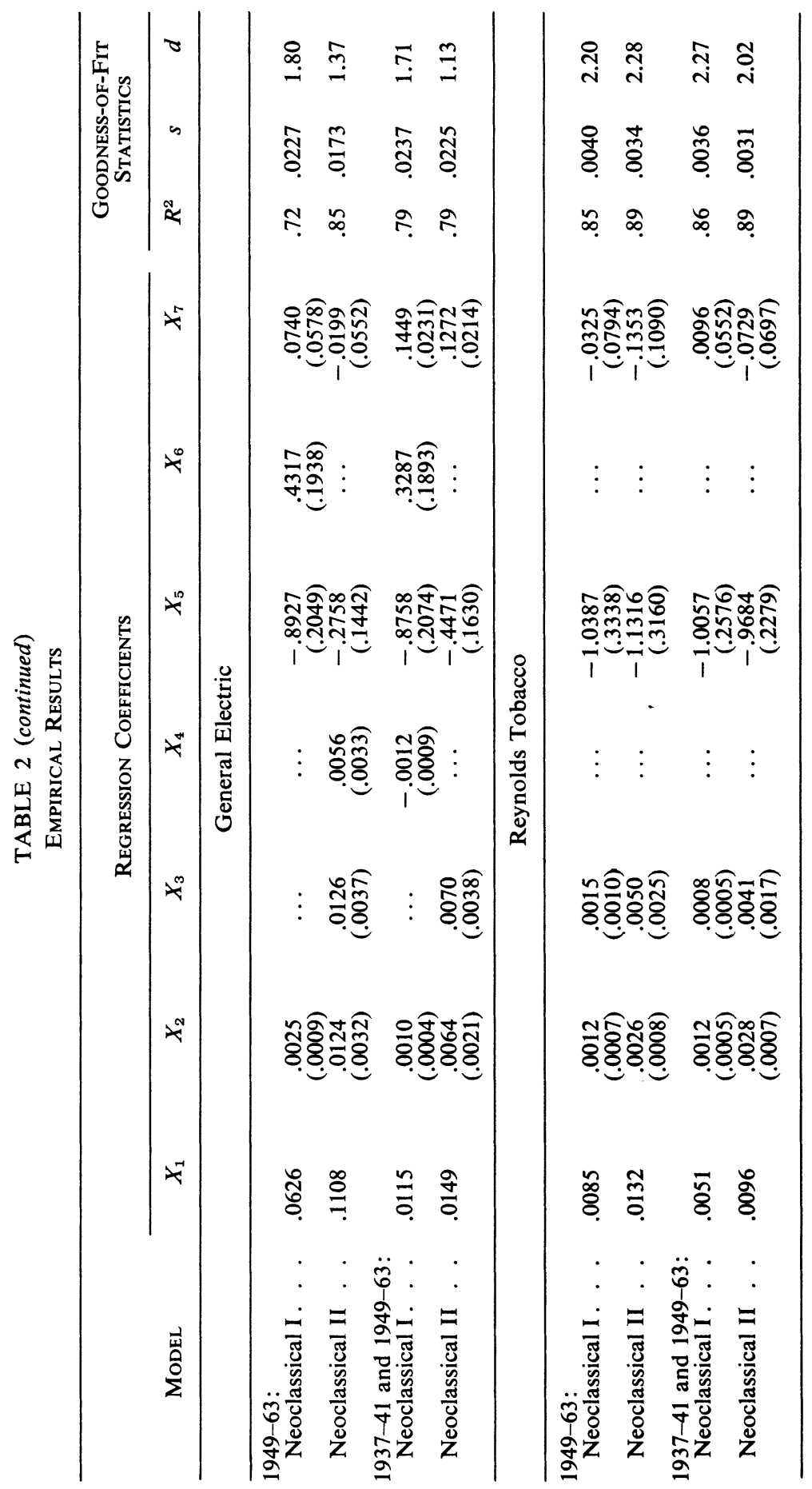




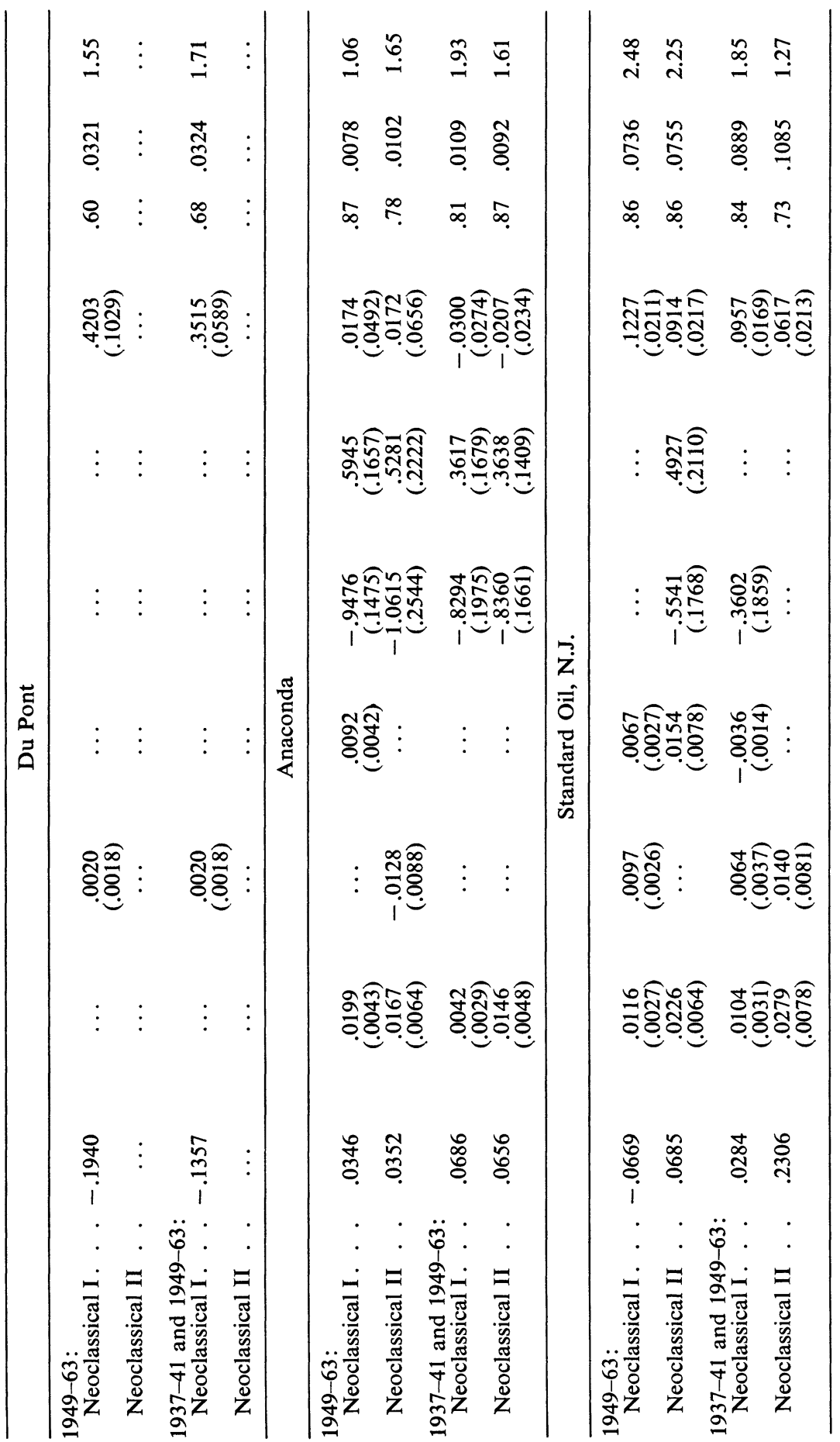




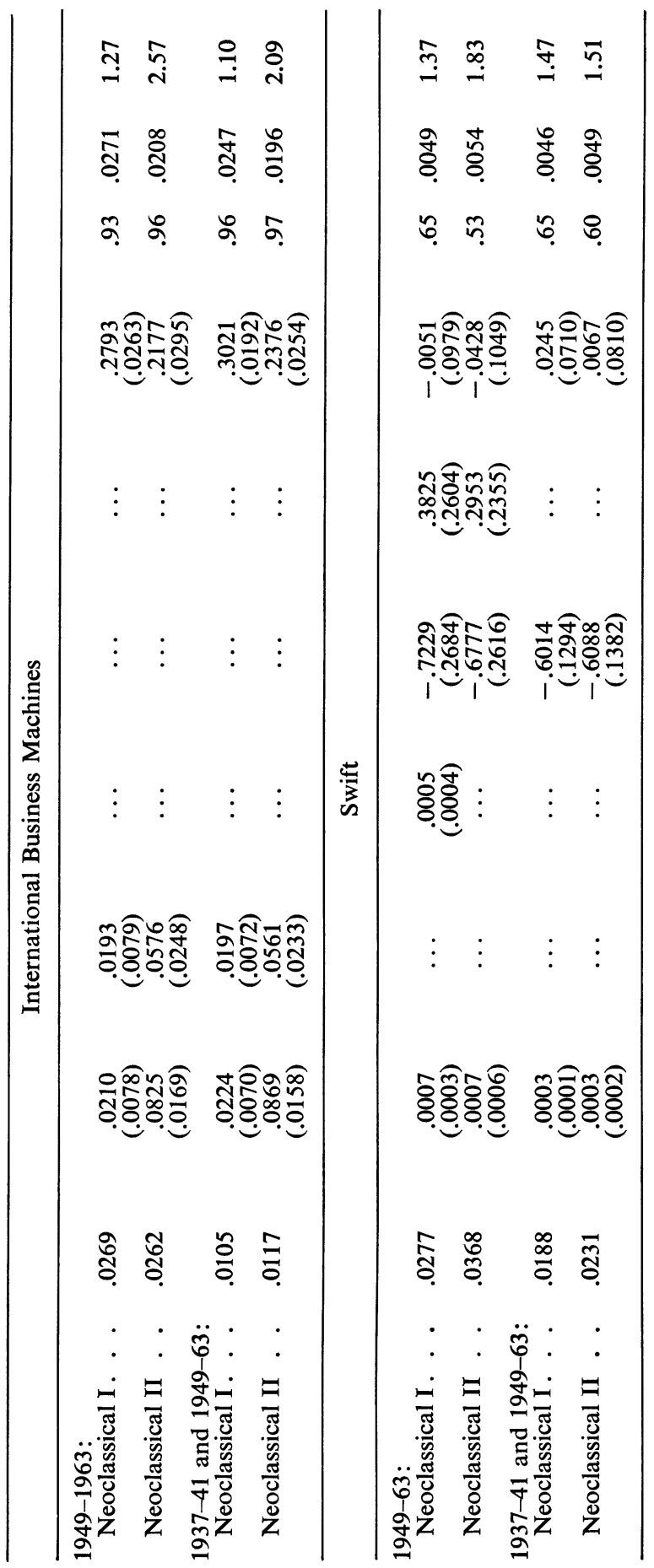




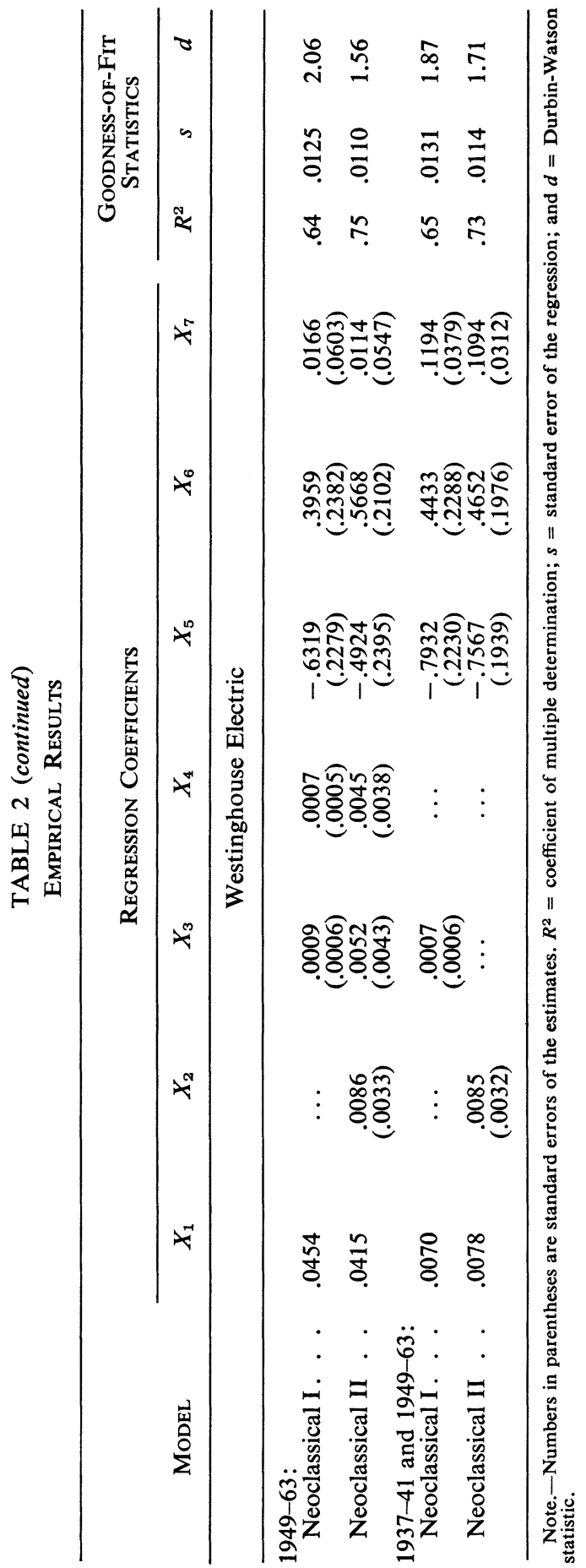




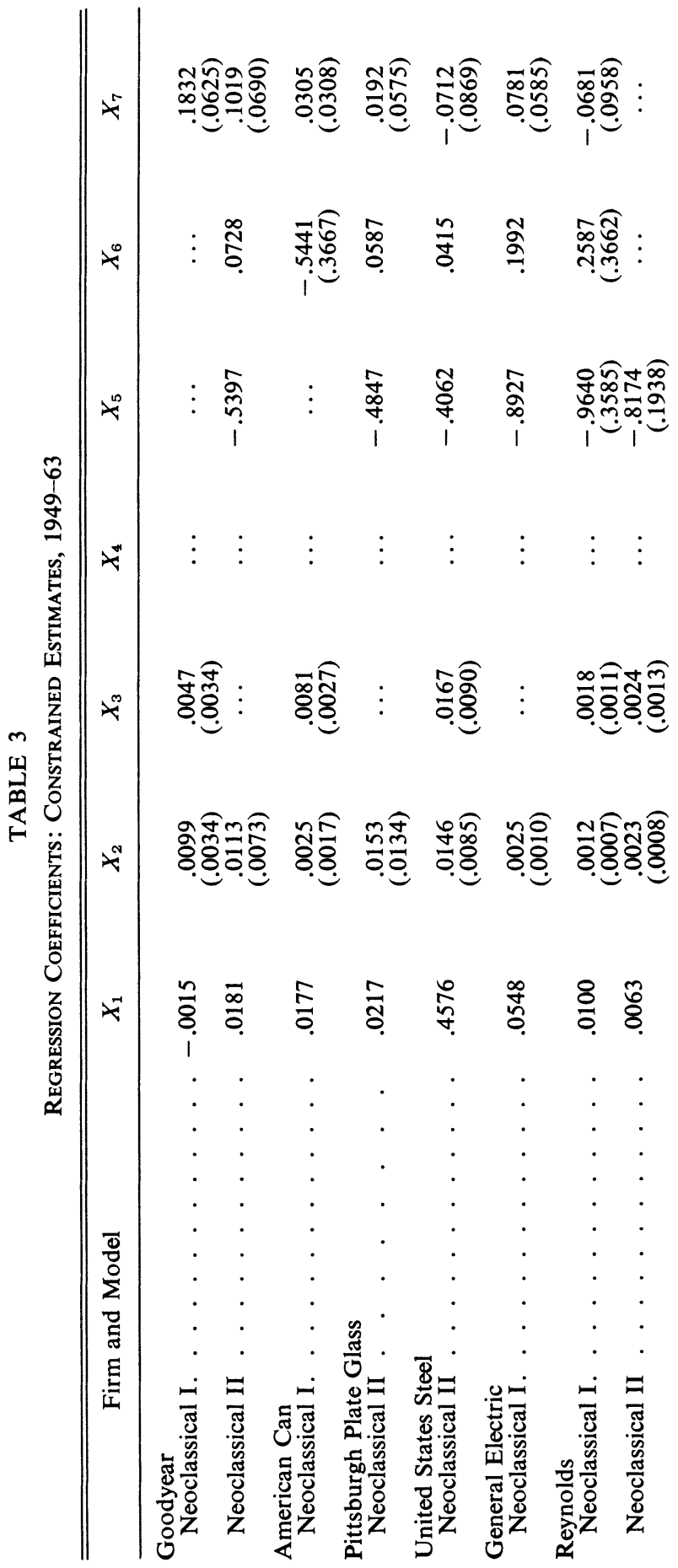




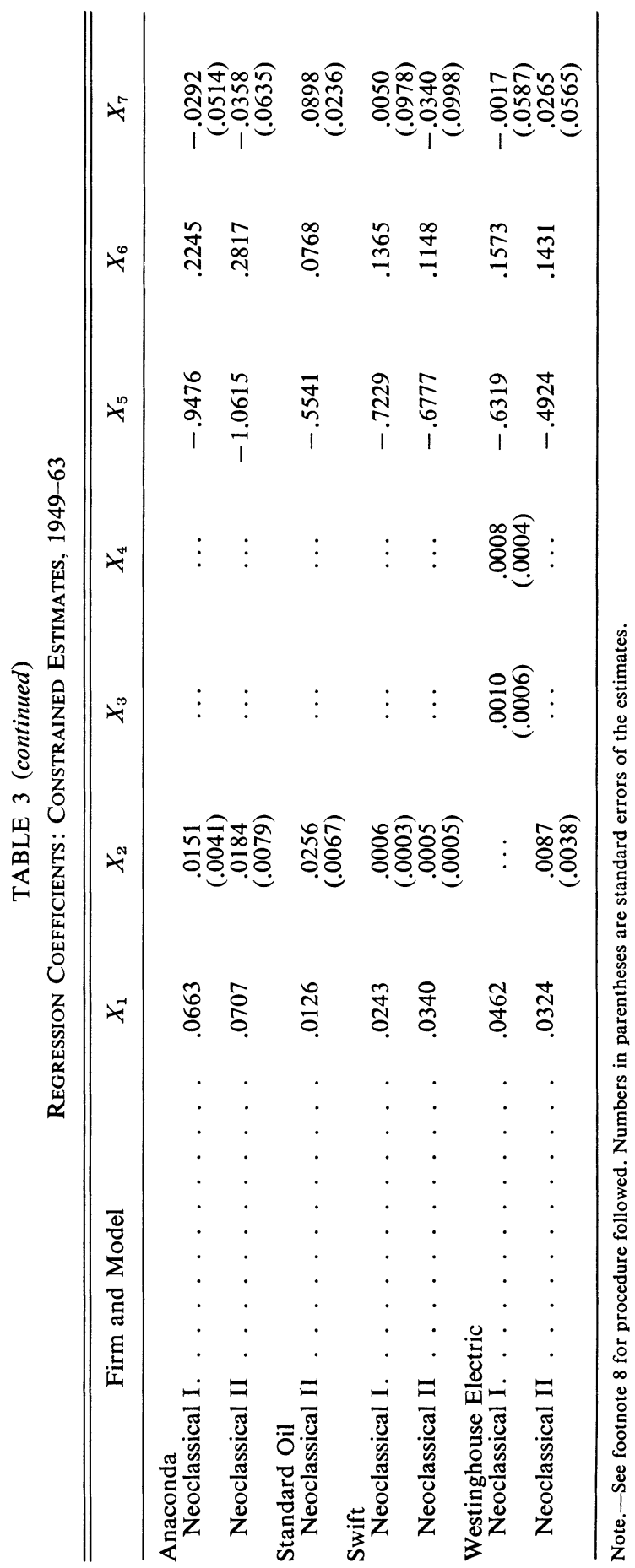


The corresponding estimates of the elasticity of output with respect to capital are given in Table 4. These estimates appear to be somewhat low; this bias is probably due to the magnification of errors of measurement in the explanatory variables through the process of first-differencing desired capital and the price of investment goods. It appears likely that the relative bias in the estimates of the parameters- $\alpha \gamma_{0}, \alpha \gamma_{1}, \alpha \gamma_{2}$-is the same. While estimates of the elasticity of output with respect to capital are biased downward, the derived estimates of the parameters $-\gamma_{0}, \gamma_{1}, \gamma_{2}$-are unaffected by the bias. ${ }^{10}$

As a test of the theory of replacement, estimates of the replacement rate from the fitted regressions may be compared with the rates computed from accounting data, as given in Table 5. For the postwar period, the hypothesis that the rates computed from the accounting data are the correct ones is rejected only once for regressions based on the best fitting model, Neoclassical I. For the Neoclassical II model, this hypothesis is rejected twice for regressions computed from postwar data. For the period as a whole, the hypothesis is rejected four times for both models. We conclude that the rates of replacement computed from accounting data are satisfactory for the postwar period for the Neoclassical I model. For the period as a whole, the fitted coefficients are generally closer to those derived from accounting data; however, the standard errors associated with the fitted coefficients are considerably smaller. Our results are generally similar to those of Jorgenson and Stephenson (1967b) for data on industry aggregates. ${ }^{11}$ The fitted replacement rates in our study are much more erratic

TABLE 4

Elasticity of OUtPut With Respect to CAPItal InPut

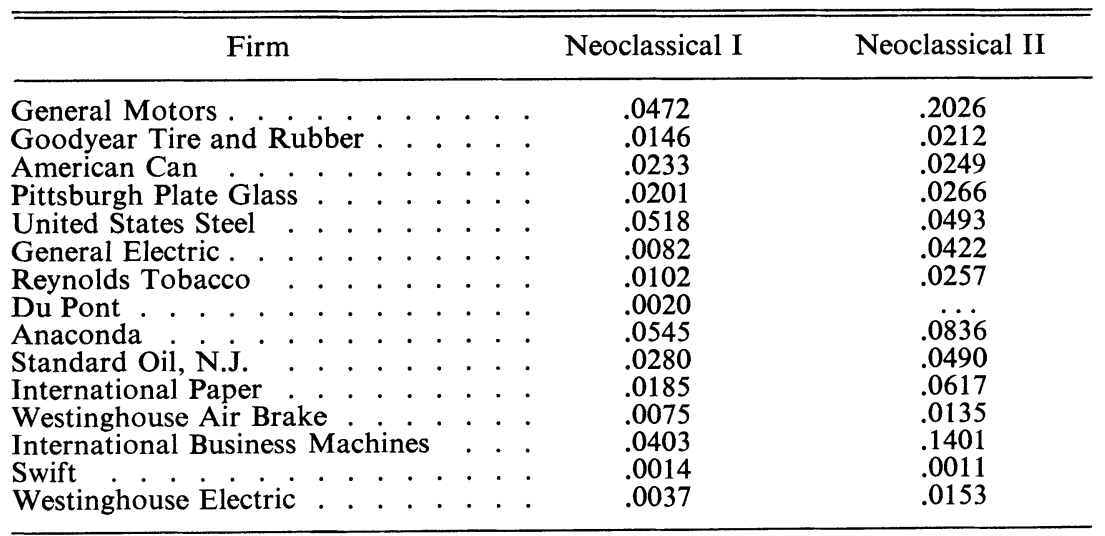

${ }^{10}$ A similar bias has been reported for a distributed lag investment function based on the hypothesis that desired capital is proportional to output; see Eisner (1967b).

${ }^{11}$ See Jorgenson and Stephenson (1967b, pp. 192-212). 
TABLE 5

ANNuAl Rates of Replacement

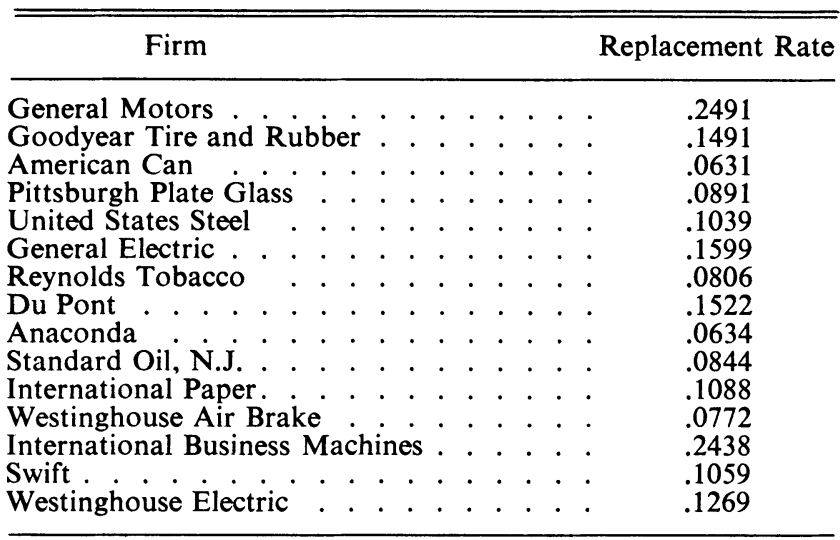

than those of Jorgenson and Stephenson, as indicated by the large standard errors associated with the corresponding regression coefficients. This is to be expected, given the much smaller number of observations for our study.

Deviations between actual investment expenditures and fitted gross investment ${ }^{12}$ provide evidence on the strong and weak points of the inclusion of capital gains as a determinant of the cost of capital and the price of capital services. Capital gains are included for Neoclassical I and excluded for Neoclassical II. A weak point of the Neoclassical I model is the explanation of investment behavior during the Korean war. For a number of firms, the change in desired capital stock variables hit a peak in 1951 in response to a rapid price rise in that year and turned sharply downward in the following year. According to the theory underlying the Neoclassical I model, positive capital gains influence investment behavior through two interrelated channels. First, positive capital gains lower the price of capital services, which raises desired capital and has a positive effect on investment. Second, if the price of capital goods increases, holders of corresponding assets receive capital gains which raise the cost of capital and hence the price of capital services. Where the capital gains are received on depreciable assets alone, the net effect will be to reduce the price of capital services and to stimulate investment expenditures. Both these influences were operating throughout 1950 and 1951; however, with the introduction of price controls and the allocation of investment expenditures on the basis of non-price considerations during the Korean war, the negligible observed

${ }^{12}$ Tinbergen charts for the regressions included in Table 2 for the postwar period are presented in a more extensive version of this paper, available from the authors. Data underlying the regressions are described in detail in a Statistical Appendix to the more extensive version. 
price change from 1951 to 1952 fails to reflect the continuation into 1952 of strong incentives to invest.

Considering the latter part of the postwar period, when non-price allocation played a less significant role, we find that the Neoclassical I model performs considerably better than Neoclassical II, particularly during the 1955-57 peak in investment expenditures. Measured capital gains were large throughout these years and helped to reinforce the incentives to invest resulting from changes in the level of output. The peak is predicted quite accurately for most firms, using the Neoclassical I model. The predicted values of investment of the Neoclassical II model, excluding capital gains, are generally lower than both the fitted values for the Neoclassical I model and the actual levels of investment. No doubt some part of the recent increase in capital expenditures can be attributed to "speculative" motives - that is, to the rate of capital gains accrued on holdings of depreciable assets. Our general conclusion is that Neoclassical I is superior to Neoclassical II in explaining postwar corporate investment behavior and that this superiority is especially marked for the period since the Korean war. We conclude that inflation does play a role in stimulating investment and that measurement of the cost of capital and the price of capital services for the prediction of investment expenditures should account for the rate of change of prices of investment goods. Our estimates of the elasticity of output with respect to capital seem to indicate that errors of measurement are of some importance; further research is required for improvements in the measurement of prices of investment goods, their rates of change, the cost of capital, and the price of capital services.

\section{Time Structure}

We turn now to characterization of the time structure of corporate investment behavior. Results from previous studies of corporate investment conflict sharply with results from surveys of new manufacturing plants by Mayer (1960). Mayer finds that the average time required from the decision to undertake investment to the completion of construction is less than two years. In econometric studies of corporate investment, Grunfeld (1960) and Kuh (1963, pp. 293-302) have found that the average lag between changes in desired capital and actual expenditures ranges from five to ten years or more. Similar results have been reported for data at the level of industry groups by Koyck (1954, pp. 74-110). For manufacturing and its subindustries, Jorgenson and Stephenson (1967a) have corroborated Mayer's survey results. They obtain average lags between changes in desired capital and actual expenditures ranging from a year and a half to three years.

There are two important differences between the econometric models of investment behavior used by Jorgenson and Stephenson and those employed by Grunfeld, Koyck, and Kuh. First, the earlier results are based on 
the flexible accelerator mechanism. Our results strongly suggest that the geometric distribution which underlies the flexible accelerator mechanism is very rarely the correct one. Of thirty distributed lag functions fitted for postwar and combined prewar and postwar data for the Neoclassical I model of investment, the geometric lag distribution is the best specification of the lag distribution for only one firm in our sample-Swift for the combined prewar and postwar period. ${ }^{13}$ A second difference between the two sets of results is the specification of desired capital. In the studies of Grunfeld, Koyck, and Kuh, desired capital was assumed proportional to the market value of the firm, the level of output, and the level of profits or sales, respectively; the results given in our previous paper suggest that both Neoclassical I and Neoclassical II specifications of desired capital provide a superior explanation of investment behavior.

We turn now to an analysis of the time structure of investment behavior for each of the firms included in our sample. To study the time structure, it is useful to derive estimates of the coefficients of the distributed lag function ${ }^{14}$ from the estimates of the parameters $\gamma_{\tau}$ and $\omega_{\tau}$ obtained from the regressions for the period 1949-63 presented in Tables 2 and 3. These estimates are presented in Table 6 in column " $\mu_{\tau}$ "; the coefficient $\mu_{0}$ corresponds to Lag 0 , the coefficient $\mu_{1}$ corresponds to Lag 1 , and so on. We present only the first six terms in the sequence. Since each sequence sums to unity, the sum of all remaining terms may be estimated as unity minus the sum of the first six terms. This estimate is called the "Remaining Lag," in Table 6. The average lags are also given in Table 6.

The distributed lag function characterized by the sequence of parameters $\mu_{\tau}$ is a relationship between net investment and changes in desired capital. To study the economic impact of changes in the determinants of desired capital-for example, changes in the tax structure-it is useful to characterize the relationship between gross investment and changes in desired capital. ${ }^{15}$ Gross investment is the sum of net investment and replacement investment. Replacement is proportional to capital stock, but capital stock depends on past gross investment, so that the coefficients of the distributed lag between gross investment and changes in desired capital are: $\nu_{0}=\mu_{0}, \nu_{1}=\mu_{1}-(1-\delta) \mu_{0}, \nu_{2}=\mu_{2}-1(1-\delta) \mu_{1}, \ldots$, where $\nu_{0}$ corresponds to Lag $0, \nu_{1}$ to Lag 1 , and so on. Estimates of these coefficients are presented in Table 6 in column " $\nu_{\tau}$."

To characterize the response of gross investment to a change in desired capital that persists for, say, $\theta$ periods of time, we calculate the sequence of cumulative sums $\xi_{\theta}$ of the sequence $\nu_{\tau}$ :

$$
\xi_{\theta}=\sum_{\tau=0}^{\theta} \nu_{\tau}=\mu_{\theta}+\delta \sum_{\tau=0}^{\theta-1} \mu_{\tau} .
$$

${ }^{13}$ Similar results are reported by Jorgenson and Stephenson (1967b, pp. 181-85).

${ }_{14}$ These estimates are derived by the method given by Jorgenson (1966, p. 146).

${ }^{15}$ For further detail, see Jorgenson (1965, pp. 79-80). 
TABLE 6

Time Form of Lagged Response (BASed on Data for 1949-63)

\begin{tabular}{|c|c|c|c|c|c|c|}
\hline \multirow[b]{2}{*}{ LAG $(\tau)$} & \multicolumn{3}{|c|}{ Neoclassical i } & \multicolumn{3}{|c|}{ Neoclassical iI } \\
\hline & $\mu_{\tau}$ & $\nu_{\tau}$ & $\xi_{\tau}$ & $\mu_{\tau}$ & $\nu_{\tau}$ & $\xi_{\tau}$ \\
\hline 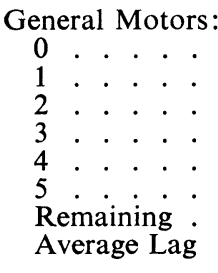 & $\begin{array}{ll}. & \\
\cdot & .3384 \\
. & .4337 \\
. & .1494 \\
. & .0514 \\
. & .0177 \\
. & .0061 \\
. & .0032 \\
. & 1.0092\end{array}$ & $\begin{array}{c}.3384 \\
.1796 \\
-.1763 \\
-.0607 \\
-.0209 \\
-.0072 \\
-.0038 \\
\ldots\end{array}$ & $\begin{array}{l}.3384 \\
.5180 \\
.3417 \\
.2810 \\
.2610 \\
.2529 \\
\ldots \\
\ldots\end{array}$ & $\begin{array}{l}.2028 \\
.3242 \\
.1751 \\
.1207 \\
.0652 \\
.0449 \\
.0672 \\
2.0260\end{array}$ & $\begin{array}{c}.2028 \\
. .1719 \\
-.0684 \\
-.0108 \\
-.0254 \\
-.0040 \\
-.0170 \\
\ldots\end{array}$ & $\begin{array}{l}.2028 \\
.3747 \\
.0364 \\
.2956 \\
.2701 \\
.2661 \\
\ldots \\
\ldots\end{array}$ \\
\hline 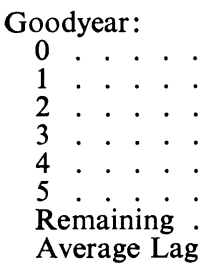 & $\begin{array}{lc}. & .6780 \\
. & .3220 \\
. & 0 \\
. & 0 \\
. & 0 \\
. & 0 \\
. & 0 \\
. & .3219\end{array}$ & $\begin{array}{c}.6780 \\
-.2550 \\
-.2739 \\
0 \\
0 \\
0 \\
0 \\
\ldots\end{array}$ & $\begin{array}{l}.6780 \\
.4230 \\
.1491 \\
.1491 \\
.1491 \\
.1491 \\
\ldots \\
\ldots\end{array}$ & $\begin{array}{l}.5330 \\
.2876 \\
.1163 \\
.0418 \\
.0141 \\
.0046 \\
.0001 \\
.7393\end{array}$ & $\begin{array}{c}.5330 \\
-.1660 \\
-.1283 \\
-.0572 \\
-.0215 \\
-.0074 \\
-.0037 \\
\ldots\end{array}$ & $\begin{array}{l}.5330 \\
.3670 \\
.2387 \\
.1815 \\
.1600 \\
.1526 \\
\ldots \\
\ldots\end{array}$ \\
\hline 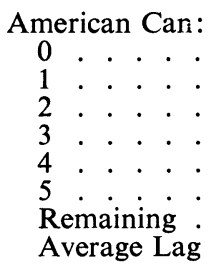 & $\begin{array}{rr} & \\
. & .1075 \\
. & .3484 \\
. & .0585 \\
. & .1896 \\
. & .0318 \\
. & .1031 \\
. & .1621 \\
. & 3.1512\end{array}$ & $\begin{array}{r}.1075 \\
.2477 \\
-.2679 \\
.1348 \\
-.1458 \\
.0733 \\
-.0865 \\
\ldots\end{array}$ & $\begin{array}{l}.1075 \\
.3552 \\
.0873 \\
.2220 \\
.0762 \\
.1496 \\
\ldots \\
\ldots\end{array}$ & $\begin{array}{l}.4096 \\
.5904 \\
0 \\
0 \\
0 \\
0 \\
0 \\
.5904\end{array}$ & $\begin{array}{c}.4096 \\
.2066 \\
-.5531 \\
0 \\
0 \\
0 \\
0 \\
\ldots\end{array}$ & $\begin{array}{l}.4096 \\
.6162 \\
.0631 \\
.0631 \\
.0631 \\
.0631 \\
\ldots \\
\ldots\end{array}$ \\
\hline 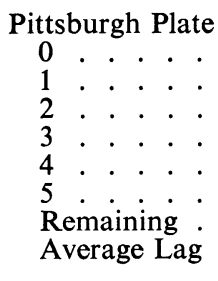 & $\begin{array}{lr}\text { Glass: } \\
. \quad .3178 \\
. \quad .3122 \\
. & .1696 \\
. & .0921 \\
. & .0500 \\
. & .0272 \\
. & .0302 \\
. & 1.4930\end{array}$ & $\begin{array}{c}.3178 \\
.0227 \\
-.1148 \\
-.0624 \\
-.0339 \\
-.0184 \\
-.0220 \\
\ldots\end{array}$ & $\begin{array}{l}.3178 \\
.3405 \\
.2257 \\
.1633 \\
.1295 \\
.1111 \\
\ldots \\
\ldots\end{array}$ & $\begin{array}{l}.5740 \\
.2782 \\
.1012 \\
.0327 \\
.0099 \\
.0029 \\
.0011 \\
.7420\end{array}$ & $\begin{array}{c}.5740 \\
-.2446 \\
-.1523 \\
-.0594 \\
-.0199 \\
-.0061 \\
-.0025 \\
\ldots\end{array}$ & $\begin{array}{l}.5740 \\
.3294 \\
.1771 \\
.1176 \\
.0978 \\
.0916 \\
\ldots \\
\ldots\end{array}$ \\
\hline 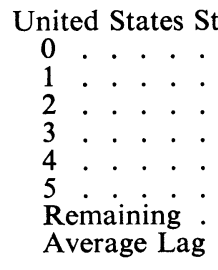 & $\begin{array}{ll}\text { teel } & \\
\cdot & .1736 \\
. & .4240 \\
. & .2065 \\
. & .1005 \\
. & .0489 \\
. & .0238 \\
. & .0226 \\
. & 1.6105\end{array}$ & $\begin{array}{c}.1736 \\
.2685 \\
-.1735 \\
-.0845 \\
-.0411 \\
-.0200 \\
-.0190 \\
\ldots\end{array}$ & $\begin{array}{l}.1736 \\
.4421 \\
.2686 \\
.1841 \\
.1429 \\
.1229 \\
\ldots \\
\ldots\end{array}$ & $\begin{array}{l}.2964 \\
.4594 \\
.1743 \\
.0517 \\
.0138 \\
.0035 \\
.0009 \\
1.0424\end{array}$ & $\begin{array}{c}.2964 \\
.1938 \\
-.2374 \\
-.1045 \\
-.0326 \\
-.0089 \\
-.0030 \\
\ldots\end{array}$ & $\begin{array}{l}.2964 \\
.4902 \\
.2528 \\
.1484 \\
.1159 \\
.1069 \\
\ldots \\
\ldots\end{array}$ \\
\hline 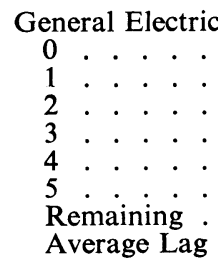 & $\begin{array}{ll}: & .3049 \\
\cdot & .2722 \\
. & .1822 \\
. & .1085 \\
. & .0605 \\
. & .0324 \\
. & .0393 \\
. & 1.6060\end{array}$ & $\begin{array}{c}.3049 \\
.0160 \\
-.0464 \\
-.0446 \\
-.0306 \\
-.0184 \\
-.0210 \\
\ldots\end{array}$ & $\begin{array}{l}.3049 \\
.3209 \\
.2745 \\
.2299 \\
.1993 \\
.1809 \\
\ldots \\
\ldots\end{array}$ & $\begin{array}{l}.2935 \\
.3791 \\
.2371 \\
.0654 \\
.0180 \\
.0050 \\
.0019 \\
1.1586\end{array}$ & $\begin{array}{c}.2935 \\
.1326 \\
-.0815 \\
-.1338 \\
-.0369 \\
-.0102 \\
-.0039 \\
\ldots\end{array}$ & $\begin{array}{l}.2935 \\
.4261 \\
.3446 \\
.2108 \\
.1740 \\
.1638 \\
\ldots \\
\ldots\end{array}$ \\
\hline
\end{tabular}


TABLE 6 (continued)

Time Form of Lagged Response (BASEd on DATA fOR 1949-63)

\begin{tabular}{|c|c|c|c|c|c|c|}
\hline \multirow[b]{2}{*}{$\operatorname{Lag}(\tau)$} & \multicolumn{3}{|c|}{ Neoclassical I } & \multicolumn{3}{|c|}{ NeOClassical II } \\
\hline & $\mu_{\tau}$ & $\nu_{\tau}$ & $\xi_{\tau}$ & $\mu_{\tau}$ & $\nu_{\tau}$ & $\xi_{\tau}$ \\
\hline 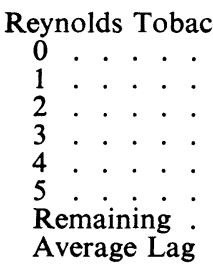 & $\begin{array}{l}\circ: \\
.1180 \\
.2908 \\
.2498 \\
.1655 \\
.0950 \\
.0487 \\
.0314 \\
2.1192\end{array}$ & $\begin{array}{c}.1180 \\
.1823 \\
-.0176 \\
-.0641 \\
-.0572 \\
-.0386 \\
-.0422 \\
\ldots\end{array}$ & $\begin{array}{l}.1180 \\
.3003 \\
.2827 \\
.2186 \\
.1614 \\
.1228 \\
\ldots \\
\ldots\end{array}$ & $\begin{array}{l}.0895 \\
.1666 \\
.1361 \\
.1113 \\
.0910 \\
.0744 \\
.3312 \\
5.0000\end{array}$ & $\begin{array}{c}.0895 \\
.0843 \\
-.0170 \\
-.0139 \\
-.0114 \\
-.0093 \\
-.0417 \\
\ldots\end{array}$ & $\begin{array}{l}.0895 \\
.1738 \\
.1568 \\
.1429 \\
.1315 \\
.1223 \\
\ldots \\
\ldots\end{array}$ \\
\hline 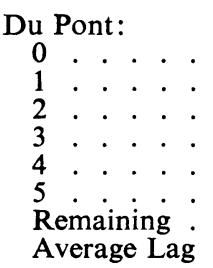 & $\begin{array}{c}0 \\
1.0000 \\
0 \\
0 \\
0 \\
0 \\
0 \\
1.000\end{array}$ & $\begin{array}{c}0 \\
1.0000 \\
.8478 \\
0 \\
0 \\
0 \\
0\end{array}$ & $\begin{array}{c}1.0000 \\
.1522 \\
.1522 \\
.1522 \\
.1522 \\
\ldots \\
\ldots\end{array}$ & $\begin{array}{l}\cdots \\
\ldots \\
\ldots \\
\cdots \\
\cdots \\
\ldots \\
\ldots\end{array}$ & $\begin{array}{l}\ldots \\
\ldots \\
\ldots \\
\cdots \\
\cdots \\
\cdots \\
\ldots\end{array}$ & $\begin{array}{l}\cdots \\
\ldots \\
\cdots \\
\cdots \\
\cdots \\
\ldots \\
\ldots\end{array}$ \\
\hline 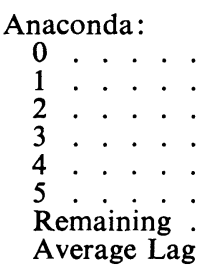 & $\begin{array}{l}.2769 \\
.2624 \\
.1865 \\
.1178 \\
.0698 \\
.0397 \\
.0470 \\
1.7999\end{array}$ & $\begin{array}{c}.2769 \\
.0030 \\
-.0593 \\
-.0569 \\
-.0406 \\
-.0257 \\
-.0342 \\
\ldots\end{array}$ & $\begin{array}{l}.2769 \\
.2799 \\
.2207 \\
.1639 \\
.1232 \\
.0976 \\
\ldots \\
\ldots\end{array}$ & $\begin{array}{l}.2202 \\
.2337 \\
.1861 \\
.1317 \\
.0874 \\
.0556 \\
.0853 \\
2.3319\end{array}$ & $\begin{array}{c}.2202 \\
.0275 \\
-.0328 \\
-.0426 \\
-.0360 \\
-.0262 \\
-.0467 \\
\ldots .\end{array}$ & $\begin{array}{l}.2202 \\
.2477 \\
.2149 \\
.1723 \\
.1363 \\
.1101 \\
\ldots \\
\ldots\end{array}$ \\
\hline 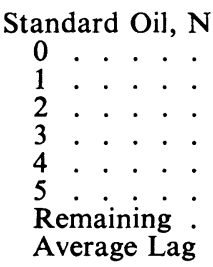 & $\begin{array}{c}\text { J.: } \\
.4163 \\
.3464 \\
.2393 \\
0 \\
0 \\
0 \\
0 \\
.8250\end{array}$ & $\begin{array}{c}.4163 \\
-.0329 \\
-.0779 \\
-.2191 \\
0 \\
0 \\
0 \\
\ldots\end{array}$ & $\begin{array}{l}.4163 \\
.3814 \\
.3035 \\
.0844 \\
.0844 \\
.0844 \\
\ldots \\
\ldots\end{array}$ & $\begin{array}{l}.5227 \\
.2896 \\
.1203 \\
.0444 \\
.0154 \\
.0051 \\
.0024 \\
.7662\end{array}$ & $\begin{array}{c}.5227 \\
-.1890 \\
-.1448 \\
-.0657 \\
-.0253 \\
-.0090 \\
-.0045 \\
\ldots\end{array}$ & $\begin{array}{l}.5227 \\
.3337 \\
.1889 \\
.1232 \\
.0978 \\
.0889 \\
\ldots \\
\ldots\end{array}$ \\
\hline 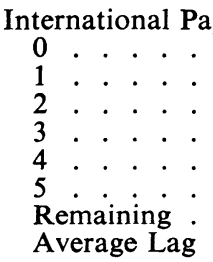 & $\begin{array}{c}\text { er: } \\
.5513 \\
.4486 \\
0 \\
0 \\
0 \\
0 \\
0 \\
.4486\end{array}$ & $\begin{array}{c}.5513 \\
-.0424 \\
-.3998 \\
0 \\
0 \\
0 \\
0 \\
\ldots\end{array}$ & $\begin{array}{l}.5513 \\
.5086 \\
.1088 \\
.1088 \\
.1088 \\
.1088 \\
\ldots \\
\ldots\end{array}$ & $\begin{array}{l}.4149 \\
.5851 \\
.0 \\
0 \\
0 \\
0 \\
0 \\
.5851\end{array}$ & $\begin{array}{c}.4149 \\
.2153 \\
-.5214 \\
0 \\
0 \\
0 \\
0 \\
\ldots\end{array}$ & $\begin{array}{l}.4149 \\
.6302 \\
.1088 \\
.1088 \\
.1088 \\
.1088 \\
\ldots \\
\ldots\end{array}$ \\
\hline 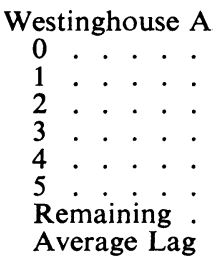 & $\begin{array}{c}\text { Brake: } \\
.6267 \\
.3733 \\
0 \\
0 \\
0 \\
0 \\
0 \\
.3733\end{array}$ & $\begin{array}{c}.6267 \\
-.2050 \\
-.3445 \\
0 \\
0 \\
0 \\
0 \\
\ldots\end{array}$ & $\begin{array}{l}.6267 \\
.4217 \\
.0772 \\
.0772 \\
.0772 \\
.0772 \\
\ldots \\
\ldots\end{array}$ & $\begin{array}{c}.5407 \\
.4593 \\
0 \\
0 \\
0 \\
0 \\
0 \\
.4592\end{array}$ & $\begin{array}{c}.5407 \\
-.0397 \\
-.4238 \\
0 \\
0 \\
0 \\
0 \\
\ldots\end{array}$ & $\begin{array}{l}.5407 \\
.5010 \\
.0772 \\
.0772 \\
.0772 \\
.0772 \\
\ldots \\
\ldots\end{array}$ \\
\hline
\end{tabular}


TABLE 6 (continued)

Time Form of LAGged Response (BASEd on Data for 1949-63)

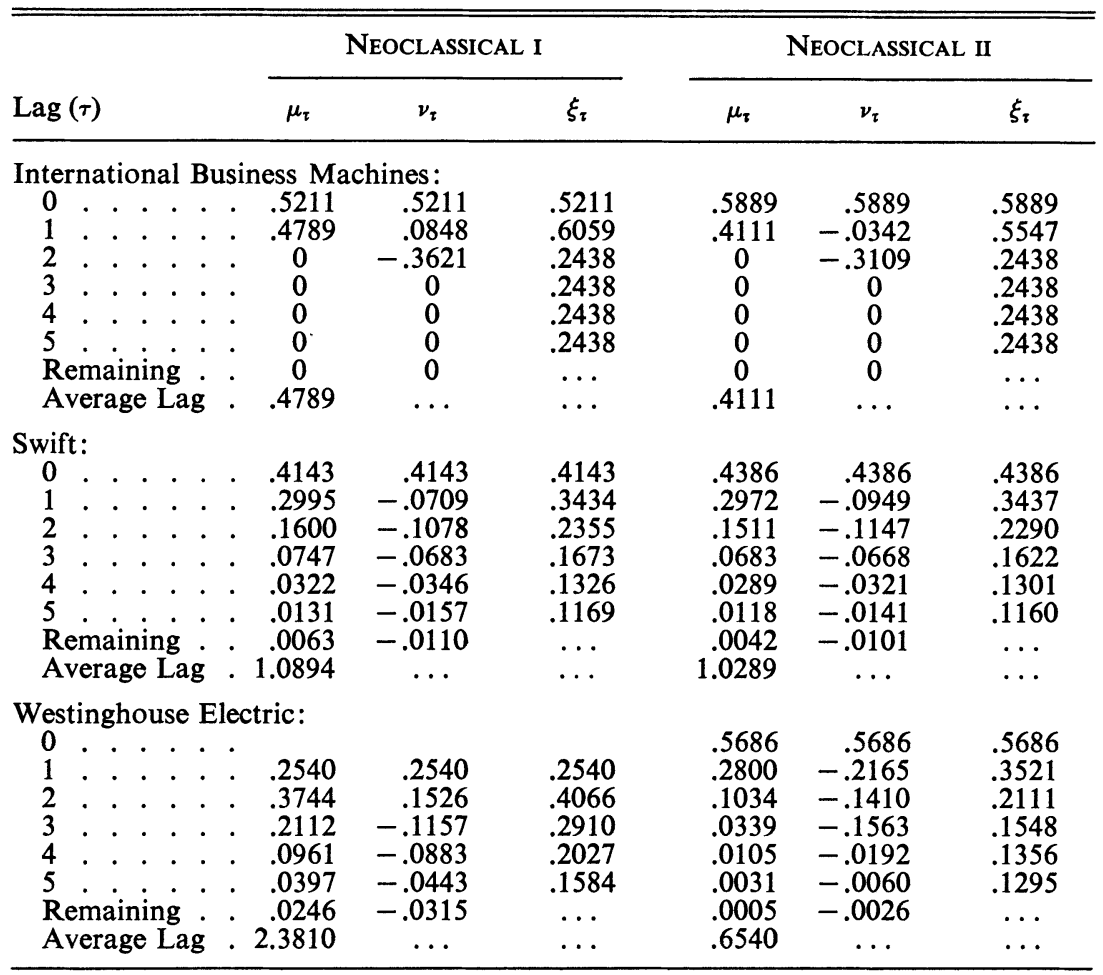

The change in gross investment resulting from a unit change in desired capital $\theta$ periods earlier is equal to the net investment, $\mu_{\theta}$, plus replacement of investments that have already taken place, ${ }^{16} \delta \sum \mu_{\tau}$. Estimates of the elements of this sequence are given in column " $\xi_{\tau}$ " in Table 6 . The sequence $\xi_{\tau}$ approaches $\delta$ as a limit; to provide an indication of the distance between the final value of this sequence given in Table 6 and the limiting value, the final value may be compared with rates of replacement for each firm given in Table 5.

The time structure of investment behavior for the firms included in our sample is similar to that for two-digit industry groupings, as characterized by Jorgenson and Stephenson (1967a). Although the range of average lags is considerably greater for individual firms than for industry groups, the average lag is concentrated in the range from one to two years. This coincides both with the estimates of Jorgenson and Stephenson and with the survey results of Mayer. The forms of the distributions are similar to those found by Jorgenson and Stephenson. For most firms, the response

${ }^{16}$ Further details are given by Jorgenson (1965, pp. 79-80) and Jorgenson and Stephenson (1967a, p. 18). 
of gross investment to a change in desired capital during the first year is quite substantial. However, for Du Pont and Westinghouse Electric this response is estimated to be zero using the Neoclassical I model. For other firms, the response ranges from .1075 for American Can to .6780 for Goodyear using Neoclassical I and from .0895 for Reynolds Tobacco to .5889 for IBM using Neoclassical II. The most common pattern from the Neoclassical I model is for the peak response of gross investment to a change in desired capital to be reached in the second year, again corroborating the results of Jorgenson and Stephenson. Gross investment then declines, usually quite smoothly. An exception is the estimated time pattern of response for American Can, which appears to be quite implausible. An equally common pattern for the Neoclassical II model is for the peak response of gross investment to be reached in the first year.

On the basis of the similarity between estimated distributed lag functions for the individual firms included in our sample and the estimated distributed lag functions for two-digit industry groups estimated by Jorgenson and Stephenson, we conclude that aggregation bias is small. Although there is greater variability among individual firms than among industry groups, the basic quantitative results on average lags and the qualitative results on the shapes of the underlying lag distributions are quite similar for individual firms and for industry groupings. We conclude, further, that the sharp conflict between previous econometric studies of the lag structure underlying investment behavior and survey results by Mayer is due to errors in specification of the lag distribution and the desired level of capital. When these errors are corrected, the distributed lag functions, both for individual firms and for industry groups, yield the same characterization of the time structure of investment behavior as the results from sample surveys.

\section{Conclusion}

The basic purpose of this paper has been to develop the implications of a theory of corporate investment behavior based on the neoclassical theory of optimal capital accumulation. This theory attributes considerable importance to the cost of capital and to the rate of capital gain or loss on assets. To test the implications of the theory for the impact of inflation on corporate investment behavior, we have developed two alternative versions of the neoclassical model of investment. In the first, Neoclassical I, the rate of change of the price of investment goods is assumed to influence investment decisions directly. In the second, Neoclassical II, the rate of change of the price of investment goods is assumed to be transitory and without direct effect on investment behavior.

A comparison of the results from fitting the two neoclassical models of corporate investment behavior to data for fifteen large manufacturing firms chosen from a wide variety of industry groups shows that inflation 
does have a substantial impact on investment, although this impact may be mitigated or offset entirely by the institution of non-price allocation mechanisms for investment, as during the Korean war. During periods such as the 1955-57 investment boom or the recent peak of investment activity, speculative motives for investment, arising from high rates of capital gain on assets, play an important role in explaining levels of investment, both during the investment peak and into the subsequent period of decline in investment expenditures. For prediction of the impact of changes in the determinants of investment expenditures in the absence of non-price allocation of investment goods, the effects of inflation must be taken into account.

A second implication of our theory of corporate investment behavior concerns the time structure of the underlying investment process. Previous characterizations of the time structure of corporate investment behavior conflict sharply with results from sample surveys and results from econometric studies of industry groups. Our empirical findings support the conclusion that this conflict is due to errors in the specification of the lag distribution and the desired level of capital in previous studies of corporate investment. Our results conform to the results of surveys and to findings from studies of industry groupings by Jorgenson and Stephenson (1967). Of course, there is more heterogeneity in the time structure of investment behavior for individual firms.

Considerable disenchantment with the economic theory of the firm has been evident in the theoretical literature, especially in the wake of the Oxford studies on the price mechanism and similar studies in the United States, as summarized in the "marginalist" controversies of some twenty years ago. ${ }^{17}$ Simon (1962) has correctly emphasized that this disenchantment is not based on an examination of empirical evidence:

I should like to emphasize strongly that neither the classical theory of the firm nor any of the amendments to it or substitutions for it that have been proposed have had any substantial empirical testing. If the classical theory appeals to us, it must be largely because it has a certain face validity... rather than because profit maximizing behavior has been observed [p. 8.]

Simon's characterization of substitutes for the classical theory of the firm is essentially correct. Although tests have been proposed that would discriminate between the classical theory of the firm and alternatives to it, for example, by Williamson (1963, 1964), empirical confirmation of alternatives to the classical theory is lacking, at least so far.

Simon's characterization of empirical evidence on the classical theory must be modified in light of econometric work on the theory of cost and production. Econometric studies of production are based almost entirely

${ }^{17}$ See Machlup (1967) for detailed references. 
on the classical theory of the firm. The empirical evidence is so largely favorable to this theory that current research is concentrated on such technical questions as the appropriate form for the production function and the statistical specification of econometric models of production. ${ }^{18}$ Our results on corporate investment behavior also support the classical theory.

Our version of the classical theory of the firm must be carefully distinguished from the atemporal theory of the elementary textbooks, excoriated by organization theorists such as Simon (1962) and by economists such as Alchian (1965), Machlup (1967), and Williamson (1963, 1964). To maximize the welfare of the shareholders of the firm, businessmen should maximize the market value of the firm at every point of time. This objective does not lead to maximization of accounting profit at every point of time or even to maximization of some long-run average accounting profit. For a model of technology such as that contained in relationships (4) and (5) of our theory of corporate investment, the objective of the firm is to maximize profit defined as the difference between revenue and outlay on current account and the implicit rental value of capital. We conclude that the empirical support for an intertemporal version of the neoclassical theory of the firm is very substantial.

The neoclassical theory of the firm, simple as it is, suffices to explain such features of corporate activity as production, relative factor intensity, and investment behavior. Of course, this evidence deals with rather gross features of the activity of the firm; a theory of the firm that is adequate for describing the productive process may not be sufficiently specific with regard to internal organization or structure of ownership to provide a useful basis for empirical studies of business organization. The problem to be solved in further development of the theory of the firm is not to provide an alternative to the neoclassical theory, but to provide a specialization of this theory that will preserve the basic results concerning optimal production and capital accumulation while providing much more specific implications with regard to the organization and control of the corporation.

\section{References}

Alchian, A. A. "The Basis of Some Recent Advances in the Theory of Management of the Firm," J. Indus. Econ., XIV (November, 1965), 30-41.

Arrow, K. J. "Optimal Capital Policy, the Cost of Capital, and Myopic Decision Rules," Ann. Inst. Statis. Math., XVI, Nos. 1-2 (1964), 21-30.

Eisner, R., "Capital . d Labor in Production: Some Direct Estimates," in Murray Brown (ed.). The Theory and Empirical Analysis of Production ("Studies in Income and Wealth," Vol. XXXI). New York: National Bureau of Economic Research, 1967. (a)

${ }^{18}$ A recent survey of the literature by Walters (1963) on cost and production functions lists 345 references, almost all presenting results of econometric tests of the classical theory of the firm. 
- "A Permanent Income Theory for Investment: Some Empirical Explorations," A.E.R., LVII, No. 3 (June, 1967), 363-90. (b)

Fortune Magazine. "Directory of the 500 Largest Industrial Corporations, 1962.

Grunfeld, Y. "The Determinants of Corporate Investment," in A. C. Harberger (ed.). The Demand for Durable Goods. Chicago: Univ. of Chicago Press, 1960.

Haavelmo, T. A Study in the Theory of Investment. Chicago: Univ. of Chicago Press, 1960.

Jorgenson, D. W. "Anticipations and Investment Behavior," in J. S. Duesenberry, E. Kuh, G. Fromm, and L. R. Klein (eds.). Brookings Quarterly Econometric Model of the United States. Chicago: Rand McNally \& Co., 1965.

- “Rational Distributed Lag Functions," Econometrica, XXXIV, No. 1 (January, 1966), 135-49.

Jorgenson, Dale W., and Siebert, Calvin D. "A Comparison of Alternative Theories of Corporate Investment Behavior," A.E.R., LVIII, No. 4 (September, 1968).

Jorgenson, Dale W., and Stephenson, J. A. “The Time Structure of Investment Behavior in United States Manufacturing, 1947-60," Rev. Econ. and Statis., XLIX, No. 1 (February, 1967), 16-27. (a)

- "Investment Behavior in U.S. Manufacturing, 1947-60," Econometrica, XXXV (April, 1967), 169-220. (b)

Koyck, L. M. Distributed Lags and Investment Analysis. Amsterdam: North Holland Publishing Co., 1954.

Kuh, E. Capital Stock Growth: A Micro-Econometric Approach. Amsterdam: North Holland Publishing Co., 1963.

Machlup, F. "Theories of the Firm: Marginalist, Behavioral, Managerial," A.E.R., LVII, No. 1 (March, 1967), 1-33.

Malinvaud, E. "Capital Accumulation and Efficient Allocation of Resources," Econometrica, XXI, No. 2 (April, 1953), 233-68.

Mayer, T. "Plant and Equipment Lead Times," J. Bus., XXXIII, No. 2 (April, 1960), 127-32.

Meyer, J., and Kuh, Edwin. The Investment Decision: An Empirical Study. Cambridge, Mass.: Harvard Univ. Press, 1957.

Modigliani, F., and Miller, M. "The Cost of Capital, Corporation Finance and the Theory of Investment," A.E.R., XLVIII, No. 3 (June, 1958), 261-97.

- "Some Estimates of the Cost of Capital to the Electric Utility Industry, 1954-57," A.E.R., LVI, No. 3 (June, 1966), 333-91.

Simon, H. A. "New Developments in the Theory of the Firm," A.E.R., LII, No. 2 (May, 1962), 1-15.

Walters, A. A. "Production and Cost Functions: An Econometric Survey," Econometrica, XXXI, Nos. 1-2 (April, 1963), 1-66.

Williamson, Oliver E. "Managerial Discretion and Business Behavior," A.E.R., LIII, No. 5 (December, 1963), 1032-57.

- The Economics of Discretionary Behavior: Managerial Objectives in a Theory of the Firm. Englewood Cliffs, N.J.: Prentice-Hall, Inc., 1964. 